\title{
Public Relations Principles for the Digital Communication in a Local Crisis
}

\author{
Antonela Zora Rezo \\ Faculty of Forestry and Wood Technology, Zagreb - Croatia \\ Matilda Kolić Stanić \\ Catholic University of Croatia, Croatia \\ Marijana Togonal \\ Catholic University of Croatia, Croatia
}

\begin{abstract}
In dealing with the crisis, all institutions must react and urgently solve the problem, but a special challenge is to communicate with key publics, especially those publics that have suffered damage., What is imperative for public relations is fast and twoway communication. That is why digital platforms are indispensable in crisis communication because they enable almost simultaneous reaction and enable institutions to communicate directly with the affected public, without the mediation of information media. This paper aims to analyse the crisis communication of the City of Slavonski Brod through its official website and Facebook page during water pollution in March and April 2018. The analysis was performed by methods of qualitative content analysis and a case study analysis. During the environmental incident, the City of Slavonski Brod did not communicate following the PR principles of crisis communication nor took advantage of digital communication.
\end{abstract}

Keywords: social networks, crisis communication, public relations, digital communication

JEL classification: D8, M1, O3

Acknowledgments: This article is based on the research conducted by Antonela Zora Rezo, mentored by Assistant Professor Marijana Togonal, Ph.D. and Matilda Kolić Stanić, Ph.D., for her master thesis on the topic Crisis communication: Water pollution in Slavonski Brod - case study, published in June 2021 at the Department of Communication Sciences, Catholic University of Croatia, Croatia.

Paper type: Research article

Received: Jun 20, 2021

Accepted: Aug 23, 2021

DOI: 10.54820/EUXG7226 


\section{Introduction}

Crises often mark the social and cultural context in which organizations operate, and anyone involved in managing organizations knows that crises are impossible to avoid (de la Cierva, 2018). Whether the cause of the crisis is external or internal, whether it is caused by environmental forces or by management irregularities (Langford, 2006), communication in such circumstances is extremely complex and demanding. Therefore, it is not surprising that crisis communication is one of the most challenging areas in public relations (Jugo, 2017). Public relations, as a relatively young profession within communication sciences, faced in 1990s the explosion of researches in crisis communication (Haupt, 2021) and still needs to put a lot of effort into educating its practitioners (Kolić Stanić, 2018).

This paper aims to analyze the use of digital communication channels in crisis communication in a local community in Croatia. We focused on the crisis communication of the City of Slavonski Brod and its official digital channels during the environmental incident of water pollution in March 2018. Since the City of Slavonski Brod has two digital channels for communication with its citizens, this paper will have two goals: the first is to analyze crisis communication during the environmental incident on the City's official website, and the second goal is to analyze crisis communication during the environmental incident on the official Facebook page of the City. The main methods of analysis are case study and qualitative content analysis. The main research question is: How does the City of Slavonski Brod follow PR principles of crisis communication during the crisis on its official digital channels.

In the field of crisis communication in Croatia, there is a lack of published research on crisis communication using new digital media, especially in local self-government. So far, there has been no research on environmental crises in Croatia from a public relations perspective that would focus specifically on the local community or the local self-government. Rare exceptions, but just at the level of mentioning the course, is the case of beer factory's water pollution (Jurčević et al., 2020), or the crisis of landmine accidents (Čerina et al., 2007), or the analysis of the case of fires on the islands of Kornati (Perinić, 2007). Still, none of these studies was observed exclusively from the perspective of public relations.

\section{Literature review}

\section{The crisis as the challenge for public relations}

The causes of the crisis, according to Lerbinger (1997), divide crises into natural and technological crises, confrontational crises, and those due to bad intentions. Furthermore, there are crises due to distorted values of board members, crises due to management errors (de la Cierva, 2018). From the perspective of public relations, the concept of crisis is complex, and different definitions emphasize its many characteristics. But at the end of the day, the crises are primarily a problem of management (de la Cierva, 2018), which is responsible for its prevention, preparation, response, and revision (Coombs, 2012). But it is not enough to solve the problem, and it is also necessary to communicate, especially during crises. Namely, crisis communication can reduce or even eliminate the negative consequences on relations with key publics (de la Cierva, 2018). Like management, organizations (no matter the type of organization) need to communicate with key audiences before, during, and after the crisis (Jugo, 2017).

Although the crisis can be an opportunity to improve an organization and even to improve its image if it is well managed (de la Cierva, 2018; Tkalac Verčič, 2015; Jugo 
2017), the crisis comes with its negative connotations - it brings organizations and individuals into serious difficulty by jeopardizing their goals and even their very existence (Coombs, 2012; de la Cierva, 2018; Jugo, 2017; Tomić, 2016). Crises are unplanned and unwanted (Tomić 2016), fast and uncertain (de la Cierva, 2018), intense and potentially negative (Jugo, 2017). They always involve blaming: whether the person has caused the problem or failed to answer it correctly (de la Cierva, 2018).

\section{Digital channels are crises (un)friendly}

With the development of new media and digital platforms, the media environment has undergone a great transformation: information is transmitted at high speed and has a global reach; emotions are emphasized, and there is a certain instability associated with the new digital world (de la Cierva, 2018). Furthermore, much communication has moved from classic channels to social networks like Facebook (Jugo, 2017). Due to all these features, digital communication channels are an indispensable tool in crisis communication (Coombs, 2012). Still, at the same time (because crises develop faster than ever and can become global in a short time), they can also be figured as double-edged swords (de la Cierva, 2018).

Online hostile communities are organized quickly (Tomić, 2016), so a singular problem can quickly turn into a crisis: such digital turbulences are taken over from the mainstream media and turn into real controversies (de la Cierva, 2018). The great trump card of social networks and digital platforms is the immediacy of communication - to reach the public, the organization can directly communicate with its key audiences through digital channels (de la Cierva, 2018). These are the concrete benefits that channels like Facebook and Twitter offer the organization to communicate faster and more efficiently in a crisis (Jugo, 2017). However, during the crisis, the public trusts the media because the organization is often not considered a credible source of information (de la Cierva, 2018). In the new digital environment, old negative news will emerge online. It may even present itself as new offline news, so the organization must interact with its public even after the crisis (de la Cierva, 2018).

\section{The principles in crises communication}

There are many tips in the literature on communicating in public that emphasize the importance of certain principles. Still, de la Cierva, with his eight principles, has managed to cover all the fundamental problems that a communicator will encounter in a crisis.

As the first principle, de la Cierva states: "Address perceptions more than facts" (de la Cierva, 2018). In short, this principle emphasizes the importance of perception and argues that facts are important but that perceptions of those facts are even more important. Furthermore, communication can only be successful if you first know how to listen to the other side - especially those who are protesting, because the answer to the crisis must not be closure (de la Clerva, 2018; Coombs, 2012; Jugo, 2017, Tkalac Verčič, 2015). The third principle emphasizes how important it is in crisis communication to emphasize feelings that show that the organization is concerned about its key publics and understands them (de la Cierva, 2018, Langford, 2006). In this way, we come to the fourth principle, which instructs the crisis communicator to communicate from the position of the public. That is after we have approached the problem given its perceived importance by key publics. After listening to the protesters and expressing our concerns to those publics, we should now answer the questions that concern the affected public the most while being clear and using 
simple and understandable messages (de la Cierva, 2018; Jugo, 2017; Langford, 2006; Tkalac Verčič, 2015). Also, each organization is accountable to both the court of law and the court of public opinion (de la Cierva, 2018; Broom, 2009). While the legal position will support limited disclosure of information, crisis communication will support full openness to the public (Coombs, 2012; Tkalac Verčič, 2015). Namely, the crisis communicator should explain to the members of the management how often what we could juridical do, sometimes it is not in the organization's best interest (de la Cierva, 2018). The sixth principle emphasizes that truth is the only way to overcome the crisis. The crisis undermines the trust of key publics in the organization, and only honest communication can restore it (Coombs, 2012; de la Cierva, 2018; Tkalac Verčič, 2015; Jugo, 2017). One of the basic principles of crisis communication is responsible for one's actions, which is a test for the credibility and reputation of the organization (de la Cierva, 2018; Jugo, 2017; Tkalac Verčič, 2015; Coombs, 2012). And the last, eighth principle that de la Cierva mentions is: to act professionally, that is, to be prepared (de la Cierva, 2018; Tkalac Verčič, 2015, Langford, 2006).

\section{Methodology}

This paper uses two research methods: a case study and a qualitative content analysis. The aim is to reach a broader view of the subject of research using the integration of different materials and evidence collected by different methods (Kohlbacher, 2006).

As a type of qualitative research, the case study was selected primarily to allow an intensive analysis of the selected unit (or system) in a defined time and space (Hancock et al., 2006). This method is suitable for analyzing individuals, events, or groups that allow an in-depth understanding of the situation (Hancock et al., 2006). The case study is characterized by analyzing different sources of information on the selected situation to be investigated. The report of the results is narrative and includes illustrative descriptions of key moments of the case (Hancock et al., 2006). This method provides a broad view of the area to be explored, allows the summarization and interpretation of the information collected, and is suitable for defining new issues and directions of research (Hancock et al., 2006).

Another method used in this paper is a qualitative content analysis which can be summarized as data and image data collection (Kohlbacher, 2006) and requires interpretation from the researcher. It is suitable for the analysis of symbolic communication (Halmi, 1996). The number of qualitative analyzes of website content is increasing, although scientists face problems with sampling Internet content due to interactivity, immediacy, multimodality, and hyperlinks (Riffe et al., 2014). Websites are unpredictable and impermanent, which can cause additional research challenges during sampling. But despite these problems, qualitative content analysis can be successfully applied to websites (Riffe et al., 2014).

In this paper, the subject of research in crisis communication on digital channels during the environmental incident in Slavonski Brod caused by an oil spill after the rupture of a 30-year-old pipeline from March 28, 2018, to April 9, 2018. And more concretely, the aim is to research eight principles of crises communication during the incident in Slavonski Brod. The City of Slavonski Brod has two channels of digital communication; therefore, this paper seeks to answer the following research questions: (i) RQ1: 1) How the content published during the crisis on the official website of the City follows the principles of crisis communication; (ii) RG2: How the content published during the mentioned crisis on the official Facebook page of the City follows the principles of crisis communication. 
Also, the content analysis was applied to newspaper content published mainly on the news portals jutranji. hr and vecernji.hr in the period from March 28 to July 19 , 2018, to obtain relevant evidence to reconstruct the situation. A total of 78 newspaper articles from the mentioned portals were analyzed, of which 51 articles were from the vecernji.hr portal, while 27 were from the jutarnji.hr portal.

\section{Results}

\section{The reconstruction of the research crises situation}

During the testing of the product pipeline, which has not been in use for 30 years, about 150 liters of petroleum products leaked at the western entrance to Slavonski Brod, the city from the Croatian east that is ranked as the sixth-largest city in Croatia.

The portal vecernji.hr was the first to report on March 28, 2018: "Due to the bursting of the pipe underground, on the surface, near the drainage channel, there was a leak of liquid like oil or gasoline. All emergency services were immediately alerted. Firefighters poured foam on the polluted plot to prevent fires, and the terrain is being repaired. The police regulate the traffic, and the citizens who drive on that part of the road are urged to be careful" (Balen, 2018a). The Slobodnica (Croatia) - Bosanski Brod (Bosnia and Herzegovina) product pipeline has not been active for 30 years. Tests were performed to convert it into a direct gas pipeline that should connect the Bosanski Brod Oil Refinery with the Croatian gas transportation system. The contract for gas supply to the refinery was obtained by "Crodux plin" for ten years (Balen, 2018a). It is part of the project of gasification and modernization of the Refinery in Bosanski Brod, intending to reduce air pollution that citizens have been warning about for years and the harmful consequences of air pollution in Slavonski Brod (Balen, 2018a).

On the same day, March 28, the director of Crodux Energetics, Radošević, stated that they had started testing the pipeline on that day. He admitted that a small number of petroleum products had been leaked. Tests were suspended, and the rupture was repaired by the end of the day. "It is estimated that more than 100 to 150 liters of derivatives could be leaked. Since the whole terrain was soaked with water, the derivative remained on its surface and caused a stench. We have rehabilitated a much larger space for precautionary measures", added Radošević and continued, "works are continuing to bring the pipeline in proper condition" (Balen, 2018a).

On the same day as the environmental incident, the association of citizens (Brođani za Brod) fighting for clean air in its city announced a protest for Friday, March 30. Namely, the activists stated that the air in the city has been smelling rotten eggs for several days now and that nothing has been done on the gasification project in Bosanski Brod (Balen, 2018a).

No one from the administration of the City of Slavonski Brod responded in those first two days. Only after two days from the environmental incident, on Friday, March 30 , on the day when the protests of the citizens were announced, the mayor Duspara announced that he had received a water analysis from the County Public Health Institute. There was a drastically high concentration of hydrocarbons in the water. It was forbidden to drink water, even after heat treatment (Balen, 2018b). The mayor convened a city's Civil Protection Headquarters meeting and announced that citizens would receive drinking water from state supplies. Also, the mayor announced that the first water samples would be taken for analysis and testing on Friday afternoon as the scale of the environmental incident diminishes (Jutarnji.hr, 2018a). 
The day after, the people of Slavonski Brod were without drinking water, and water cisterns started coming from Zagreb. The chief of the Croatian Government, Andrej Plenković, and other ministers were attending the Civil Protection Headquarters of the City of Slavonski Brod. It was agreed that the water supply system of Slavonski Brod will be connected to the water pumping station in Sikirevci, village nearby Slavonski Brod, in 10 to 15 days. Until then, the citizens will receive water from state stocks. It was concluded that water costs would be reduced for citizens and that criminal charges would be filed (Hina et al., 2018). Mayor Duspara told the Croatian News Agency (Hina): "I have filed a criminal complaint against Crodux. It is known here who is responsible for this pollution. In addition, they tried to reduce the scale of pollution..." (Hina et al., 2018). Crodux replied that water pollution in Slavonski Brod could not be linked to the spillage of 150 to 200 liters of gasoline. The company continues to carry out all prescribed activities related to remediation (Jutarnji.hr, 2018a). On March 31, the city of Slavonski Brod filed a criminal complaint with the County Criminal Attorney's Office, but against an unknown perpetrator.

On April 2 (the fourth day after the citizens of Slavonski Brod were forbidden to drink water from the system, i.e., on the sixth day after the pipeline burst), the connection of the city water supply system began, which was attended by Minister Ćorić and General Manager of Croatian Water (Hrvatske vode) Đuroković. The mayor came uninvited to the event and asked questions to those present: "Although you did not call us, we came to Sikirevci due to concerns about the absence of the third finding of water quality. We are concerned that the examination failed at the Croatian Institute of Public Health in Zagreb. ... Are you hiding something from the citizens of Slavonski Brod?" (Hina, 2018a).

The next day, April 3, the city authorities posted a video on their official website claiming that gasoline was still leaking from the pipeline into the water protection area (Večernji list, 2018a, net.hr, 2018). Namely, on that day, representatives of the City came to the site of the environmental incident in the morning, accompanied by a laboratory assistant from an independent laboratory for environmental testing to take in-depth samples of contaminated soil and found that gasoline flows smoothly all the time (Večernji list, 2018a). That was denied by Crodux (Jutarnji.hr, 2018b), and the media stopped reporting on the incident the video was talking about. It remained unclear which side was telling the truth.

In the following days, media conflicts continued between the mayor Duspara and the Minister of Environment and Energy Ćorić: Ćorić accused the local government of neglecting the pumping station (Hina, 2018b), and Duspara called on Ćorić to resign (Jutarnji.hr, 2018c). The Green Action movement (Zelena akcija) also called on the Croatian Government to take responsibility. All this time, the citizens of Slavonski Brod did not have the information they needed, according to the Brod Mammas Association (Brodske mame). The media reported the despair of the citizens because they drank polluted water, even babies, and many had stomach cramps, diarrhea, and vomiting (Večernji list, 2018b).

According to the findings of the Expert Commission for Water intended for human consumption, the water has been safe for human consumption since April 4 . It has been further analyzed in two independent laboratories. Also, the water from state supplies remained available. The next day, journalists in front of the residence of the Croatian Government at St. Mark's square in Zagreb offered ministers a glass of water from Slavonski Brod: Minister of the Sea, Transport, and Infrastructure Butković and Minister of Environment and Energy Ćorić drank a glass of water, while Minister of Health Kujundžić refused an offer (Hina, 2018b). 
The second protest on April 7 gathered several hundred citizens in Slavonski Brod. The conclusion of the crisis can be considered to have happened on April 9, 2018: the recommendation of the Public Health Institute of Brod-Posavina County, the Expert Commission, and the competent Ministry was issued that the water in Slavonski Brod is safe to drink and that it will be regularly analyzed (The City of Slavonski Brod, 2018a).

However, the citizens' dissatisfaction has not been resolved because the third protest took place on April 14 in front of the Croatian Government on St. Mark's Square in Zagreb, where about 200 citizens of Slavonski Brod gathered with the message that they have the right to breathe clean air, drink clean water and live with dignity in their city. The protesters were received by the head of government, Andrej Plenković, and Minister of Environment and Energy Ćorić (Hina, 2018c).

Crodux once again held a press conference at which it was ruled out the connection between pipe bursts and drinking water pollution in Slavonski Brod. Mayor Duspara stated that all institutions had failed and had no necessary information to manage the crisis. The citizens of Slavonski Brod, through their associations, once again emphasized distrust in institutions, disappointment with the whole case of water pollution, and the long-term failure to address the serious issue that worries them most - increasing malignant diseases in children and lack of studies showing why are children dying for several years (Romić, 2018).

In July of the same year, the environmental incident in Slavonski Brod took its toll: the pollution happened by accident, and no one was to blame - investigators found that there was no cause-and-effect relationship between petrol leaks from Crodux's pipeline and drinking water pollution (Bohutinski, Balen, 2018).

Exactly one year after this environmental incident, on March 28, 2019, it was announced that Čermak's company "Crodux plin" sold its business with natural gas, liquefied petroleum gas (LPG), and electricity to Slovenian Petrol and its subsidiary Geoplin. Finally, in January 2021, the Slovenian oil company Petrol took over the Croatian gas station chain Crodux, also owned by Čermak (Vecernji.hr et al., 2021).

\section{Did the posts on the websites follow the rules of crisis communication?}

The City of Slavonski Brod published 32 announcements on its official website during the ecological crisis (from March 28 to April 9, 2018). The first announcement related to the incident was being published only on the second day after the outbreak of the crisis. Most publications were published on March 31, ten of them, and towards the end of the crisis, there were fewer and fewer - one to two publications a day. On the same day that they announced at the press conference that the water was not drinkable (March 30, 2018), and with an interval of two days after the outbreak of the environmental incident, four posts were posted on the website. Information on the distribution of drinking water, provided by the Government of the Republic of Croatia, came only a day later, on March 31, 2018, when drinking water arrived in the City.

However, the mayor's statements, recordings from press conferences, photographs, or other materials that journalists would welcome for their work are not available in the PR section. Furthermore, on the City's website, most of the press releases were published under the News section, thirty of them, and two under the Public Relations section, which is intended primarily for the media, therefore should include invitations to press conferences and press releases by the City Administration (The City of Slavonski Brod, 2021). The press releases are mainly for information purposes: they list the locations where citizens can get drinking water and the phone 
numbers for more information related to the environmental incident (The City of Slavonski Brod, 2018b). They also provide on-call telephone lines (The City of Slavonski Brod, 2018c).

An analysis of the press releases showed that none of the released materials showed the City taking responsibility for the environmental incident. On the other hand, it is evident that in 13 publications, the City distances itself from the problem and states that they have nothing to do with it: "The culprit for the ecological ordeal in Slavonski Brod will be held criminally liable, and the citizens of Slavonski Brod and the surrounding area must know that they will be provided with a permanent source of drinking water [...]." (The City of Slavonski Brod, 2018d). A statement issued on April 6, 2018, also included a statement by mayor Duspara: „Unfortunately, even though both the City and the Headquarters did everything possible to protect the health of citizens in the shortest possible time, in recent days we have witnessed distortions, so part of the responsibility is transferred to us who first alerted the authorities about the environmental disaster" (The City of Slavonski Brod, 2018e).

The official website of the City did not react to the protests of the citizens. Also, although the expression of concern was noticed in 19 publications, most of the publications did not emphasize emotions. The publications offer an official way of expression, exclusively to inform the public. The posts do not contain words of sympathy or regret for what happened.

Analyzing the revelations for truthfulness, it was difficult to confirm the accuracy of the information about the multi-day spill of gasoline into the ground. For example, on April 4, 2018, a press release was issued stating: "The extent of the ecological catastrophe in Slavonski Brod is sufficiently indicated by the fact that as part of the works on remediation of the contaminated soil, only in the period from 12.00 yesterday to this morning at 4.00 a total of 30,000 liters of liquid were removed from the place of pollution" (The City of Slavonski Brod, 2018f). Namely, in the same period, the media published different data and a statement from Crodux, stating that 150 liters of petroleum products leaked around the pipe rupture. Somewhat later, local and national media reported a video of the gasoline spill. Still, apart from Crodux's reaction to the video, no additional media announcements confirmed or denied this video. Also, the mayor had stated that he had filed a lawsuit against Crodux, and it later turned out that he had filed a lawsuit against an unknown perpetrator.

\section{Did the posts on the Facebook pages follow the rules of crisis communication?}

The City of Slavonski Brod published 19 posts on its official Facebook pages during the environmental crisis (from March 28 to April 9, 2018). They did not have posts on their official Facebook profile every day. Nothing related to this environmental incident was announced in three days of April: April 3rd, 4th, and 7th, 2018. The highest number of publications was, as on the website of the City of Slavonski Brod, on March 31, 2018, when nine of them were published. Most of these posts, 12 of them, are just links to the posts on the website with a short caption. The rest of the posts are photos with accompanying description (4), text status (2), and video with accompanying description (1), and all related to the environmental incident. Not surprisingly, these posts also have a mostly informative purpose.

Posts that were not adapted to the medium on which they were published prevailed: only 8 of them were adapted to the medium - with a concise and clear accompanying description, or the posts contained photos and video that were adapted or the link to the official website published correctly (without bugs). The 
most shared (72 times) were the announcements from March 31, 2018, which informed the citizens that the water was provided from state stocks (The City of Slavonski Brod, Official Facebook page, 2018a), and in the second place was the announcement related to the environmental incident that took place in Slavonski Brod on March 28 which was shared 66 times (The City of Slavonski Brod, Official Facebook page, 2018b). On the day when the City announced through a press conference that the water was not drinkable (March 30, 2018), they had only one post on the Facebook page, warning citizens of the current situation and appealing to the Croatian Government for help.

Most comments are in two posts, which are the most shared. Negative comments prevailed, and only one comment was answered. This was a comment on the post from March 31, which lists the locations with water tanks. Answering the question of the citizen whether the cisterns are going to come to her part of the town, the City responded: "Dear madam, these are the first locations. No part of the city has been forgotten. Follow all further information on the official website of the City and via Facebook" (The City of Slavonski Brod, Official Facebook page, 2018a).

Among the comments on the post from March 30, 2018, which warned citizens not to use water in any way, was the name-calling of Mayor Duspara, who responded to these comments from his personal Facebook page: "What should I answer? I was the first to point out the problem. If I hadn't held a press conference today and set up ministries, we wouldn't have found out. And I drank water like everyone else in Brod" (The City of Slavonski Brod, Official Facebook page, 2018b). One of the Facebook users also noticed that the administrators of the City's official website deleted some comments, so he reacted: "WOW!!! For the information to the administrator - delete the posts; there will be so many of them that you will not be able to delete them!!!" (The City of Slavonski Brod, Official Facebook page, 2018b).

However, in the comments, the citizens warned of shortcomings in the City's communication with the key publics: "So the water is not drinkable. There is no water in front of local communities, there is no water in shops and what should people do?? People are already poisoned, have diarrhea and nausea. Couldn't you go through Brod with the cars that have a loudspeaker and inform the people? Many older people don't have Facebook, they don't listen to the radio, and they don't even know. And the water bills will be received on time" (The City of Slavonski Brod, Official Facebook page, 2018b). The City did not respond to that comment.

With the comments, the people of Brod also appealed to environmental associations: "Greenpeace Croatia, what do you say about this environmental incident? ... There is no bigger environmental problem in Croatia than this, for 9 years now. Where are you? Where's the money?" (The City of Slavonski Brod, Official Facebook page, 2018c).

Regarding expressing feelings, these publications are also informative and do not express regret for the situation.

\section{Discussion}

After the research results are presented, it remains to answer the research questions. Based on everything presented so far, it turned out that the principles of crisis communication were not followed on both digital communication channels of the City of Slavonski Brod.

Still, the response of the City of Slavonski Brod was not timely. Namely, as already mentioned, crisis communication requires a quick and effective response of the institution to the crisis (de la Cierva, 2018). Furthermore, the Internet and social networks have changed the way people communicate, and public relations 
practices need to adapt to this (Tkalac Verčič, 2015). On both digital channels, shortcomings are noticed. For example, the official website has a Public Relations section in which there are only two invitations to press conferences.

In contrast, there are press releases (from crisis headquarters sessions) in the News section that are more suitable for journalists than for citizens. The content was mostly not adapted to this media on the official Facebook page, and the comments were almost unresponsive. This is indeed an omission, as social networks offer an important opportunity to increase the reach of communication (Motion et al., 2016), especially for receiving feedback from its key publics (Jugo, 2017). The analysis also showed that the City of Slavonski Brod does not fully understand the motives for which its citizens are angry. Thus, the post on Facebook contains a comment from the mayor's profile in which it is stated that he did not understand the anger of the citizens. "What should I answer? I was the first to point out the problem. If I hadn't held a press conference today and set up ministries, we wouldn't have found out. And I drank water like everyone else in Brod" (The City of Slavonski Brod, Official Facebook page, 2018b).

Furthermore, none of the digital channels responded to the protests held in Slavonski Brod and Zagreb. To communicate effectively during a crisis, it is first necessary to understand the group on the other side (de la Cierva, 2018, Langford, 2006). The crisis communicator must listen to those protesting and disclose all important and necessary information for citizens (de la Cierva, 2018; Coombs, 2012; Jugo, 2017, Tkalac Verčič, 2015). Every crisis is extremely emotional but in the announcements on digital channels. However, they expressed concern, and they did not express sympathy with the citizens, which is one of the principles that should not be ignored in a crisis (de la Cierva, 2018). As for taking responsibility, in this crisis, no one has taken responsibility. In the analyzed publications of the City of Slavonski Brod, the shifting responsibilities prevail. However, one of the principles of crisis communication is the responsibility for one's actions, which is a test for the credibility and reputation of the organization (de la Cierva, 2018; Jugo, 2017; Tkalac Verčič, 2015; Coombs, 2012).

About the principle of truthfulness, it is worth mentioning the statements in which the mayor Duspara announces a lawsuit against the company Crodux. In the end, he raises it against an "unknown perpetrator." Also, the information released a few days after the incident about the amount of gasoline leaked contradicts the official report. There are no explanations, rejections, or additional corrected information about the several-day petrol leak. Such a situation disable restoring the citizens' trust, and restoring the trust is the fundamental goal of crisis communication. As pointed out, the crisis undermines the trust of key publics in the organization, and honest and truthful communication is the only way to restore it (Coombs, 2012; de la Cierva, 2018; Tkalac Verčič, 2015; Jugo, 2017). The protests after the announcement that the water was drinkable again show that the trust has not been restored.

\section{Conclusion}

A new digital world changed the way of communication (de la Cierva, 2018) and moved it more toward social networks such as Facebook (Jugo, 2017). Digital channels have become indispensable in crisis communication, especially because of their speed (Coombs, 2012) and the immediacy and interaction they allow in the organization's communication with its key audiences.

Unfortunately, the advantages of digital channels in the crisis communication of the city of Slavonski Brod during the environmental incident in 2018 - have not been fully recognized. For example, digital channels enable fast response and two-way 
communication, but the City's reaction was delayed, and one-way communication prevailed. Furthermore, the basic principles of crisis communication are applied to digital channels, as previously stated, and in this case, they were largely absent.

The limitation of this research is certainly the sample. Although the analysis covered the entire digital communication of the City of Slavonski Brod, the limiting circumstance is the number of publications. Therefore, the results of this research could be used as a direction for furthermore comprehensive research that would provide a complete insight into the crisis communication of Slavonski Brod during the environmental incident. For example, based on the findings presented in this paper, citizens' trust could be further examined regarding how the city government approaches environmental problems.

Also, this research noticed a lack of research on crisis communication in sector of local self-governing in Croatia, especially regarding digital communication channels, which may indicate that this is a great challenge for scholars.

\section{References}

1. Balen, V. (2018a), "Environmental incident in Slavonski Brod: 150 liters of petroleum products leaked (in Croatian)", available at: https://www.vecernji.hr/vijesti/ekoloskiincident-u-slavonskom-brodu-iscurilo-do-150-litara-derivata-1235783 (December 12, 2020)

2. Balen, V. (2018b), "The water in Slavonski Brod is not safe to drink even after heat treatment! (in Croatian)", available at: https://www.vecernji.hr/vijesti/oprez-voda-uslavonskom-brodu-i-okolici-nije-zdravstveno-ispravna-1236315 (December 12, 2020)

3. Bohutinski, J., Balen, V. (2018), "The water was polluted by one of the workers at the pumping station (in Croatian)", available at: https://www.vecernji.hr/vijesti/dorhkonacno-otkrio-razlog-zaga-enja-vode-u-sl-brodu-dogodilo-se-slucajno-1259288 (December 12, 2020)

4. Broom, G. M. (2009), Cutlip \& Center's Effective Public Relations (in Croatian), MATE, Zagreb.

5. Čerina, J., Zgrabljić Rotar, N. (2009), "Crisis communication and media: press coverage of mine accidents (in Croatian)", Medijska istraživanja, Vol. 15 No. 1, pp. 143-163.

6. Coombs, W. T. (2012), Ongoing Crisis Communication: Planning, Managing, and Responding, SAGE, Los Angeles.

7. de la Cierva, Y. (2018), Leading Companies through Storms and Crises: Principles and Best Practices in Conflict Prevention, Crisis Management and Communication, Pearson, Madrid.

8. Halmi, A. (1996), Qualitative methodology in the social sciences (in Croatian), Zagreb A. G. Matoš d. d., Samobor.

9. Hancock, D. R., Algozzine, B. (2006), Doing Case Study Research, Teachers College Press, Columbia University, New York and London.

10. Haupt, B. (2021), "The Use of Crisis Communication Strategies in Emergency Management", Journal of Homeland Security and Emergency Management, Vol. 18 No. 2, pp. 125-150.

11. Hina (2018a), "UNPLEASANT CONFLICT AT THE WATER PUMPING The mayor arrived uninvited and said to the minister: 'Are you hiding something from Brod !? (in Croatian)", available at: https://www.jutarnji.hr/vijesti/hrvatska/neugodan-sukob-navodocrpilistu-gradonacelnik-nepozvan-stigao-i-porucio-ministru-krijete-li-nesto-odbrodana-7197204 (December 12, 2020)

12. Hina (2018b), "ĆORIĆ ACCUSES THE LOCAL AUTHORITY OF NEGLIGENCE AROUND THE PUMPING STATION "If you had changed the filters eight years ago, this catastrophe would not have happened! (in Croatian)"'," available at: https://net.hr/danas/hrvatska/snimka-koja-dokazuje-da-nafta-jos-curi-policija-jeodmah-udaljila-novinare-ali-i-gradonacelnika-ae6da3d4-b1 c2-11 eb-a9810242ac13004d (December 12, 2020) 
13. Hina (2018c), "PHOTO: 'WE PAY YOU, AND YOU POISON US' Several hundred citizens of Slavonski Brod protested in the center of Zagreb, received by Plenković (in Croatian)", available at: https://www.jutarnji.hr/vijesti/hrvatska/foto-mi-vas-placamo-a-vi-nastrujete-nekoliko-stotina-gradana-slavonskog-broda-prosvjedovalo-u-sredistu-zagrebaprimio-ih-plenkovic-7242618 (December 12, 2020)

14. Hina, Večernji list (2018), "The culprit for the ecological ordeal in Slavonski Brod will be held criminally liable (in Croatian)", available at: https://www.vecernji.hr/vijesti/slbrod-bez-pitke-vode-stigle-cisterne-duspara-umiruje-nema-razloga-za-paniku-1236346 (December 12, 2020)

15. Jugo, D. (2017), Crisis communication management (in Croatian), Školska knjiga, Zagreb.

16. Jurčević, M., Vuletić, A. (2020), "Crisis communication - a case from Croatia (in Croatian)", South Eastern European Journal of Communication, Vol. 2 No. 1, pp. 127135.

17. Jutarnji.hr (2018a), "CRODUX ANNOUNCES POLLUTED WATER IN SLAVONSKI BROD 'Leakage of 150-200 liters of gasoline from the product pipeline cannot be linked to pollution (in Croatian)"', available at: https://www.jutarnji.hr/vijesti/hrvatska/izcroduxa-se-oglasili-o-zagadenoj-vodi-u-slavonskom-brodu-istjecanje-150-200-litarabenzina-iz-produktovoda-ne-moze-se-dovesti-u-vezu-sa-zagadenjem-7193016 (December 12, 2020)

18. Jutarnji.hr (2018b), "ANGRY IN CRODUX AFTER THE VIDEO OF GASOLINE LEAKING APPEARED: We sympathize with the people of Brod, but the claim that gasoline has been leaking for 6 days is incorrect and malicious (in Croatian)", available at: https://www.jutarnji.hr/vijesti/hrvatska/u-croduxu-bijesni-nakon-sto-se-pojavila-snimkacurenja-benzina-suosjecamo-s-brodanima-ali-tvrdnja-da-benzin-curi-vec-6-dana-jenetocna-i-zlonamjerna-7201461 (December 12, 2020)

19. Jutarnji.hr (2018c), "DUSPARA ANGRY AT ĆORIĆ AGAIN The findings are not correct, let the minister show the results! He is young and does not know. In a normal country, he would have resigned a long time ago (in Croatian)", available at: https://www.jutarnji.hr/vijesti/hrvatska/duspara-opet-ljutit-na-corica-nalazi-nisuispravni-neka-ministar-pokaze-rezultate-mlad-je-i-ne-zna-u-normalnoj-zemlji-vec-biodavno-dao-ostavku-7201329 (December 12, 2020)

20. Kohlbacher, F. (2006), "The Use of Qualitative Content Analysis in Case Study Research", Qualitative Social Research, Vol. 7 No. 1, pp. 1-30.

21. Kolić Stanić, M. (2018), "Education as the Essential Part of Public Relations Ethics Codes", in Milković, M. et al. (Eds.), ENTerprise REsearch InNOVAtion Conference, 6-8 September, 2018, Udruga za promicanje inovacija i istraživanja u ekonomiji "IRENET", Zagreb, pp. 98-104.

22. Langford, M. (2006), "Crises public relations management", in Tench, R., Yeomans, L. (Eds.), Discovering public relations (in Croatian), Biblioteka Print, Zagreb, pp. 396-413.

23. Lerbinger, O. (1997), The Crisis Manager: Facing Risk and Responsibility, Lawrence Erlbaum Associates Mahwah, New Jersey.

24. Motion, J., Heath, R. J., Leitch, S. (2016), Social Media and Public Relations. Fake friends and powerful publics, Routledge Taylor \& Francis Group, New York.

25. net.hr (2018), "NEW VIDEO REVEALS THAT GASOLINE HAS LEAKED FOR 6 DAYS? MINISTER TRANSFERS THE BALL TO LOCAL AUTHORITIES / 'Back in 2010, you should have changed the filter! (in Croatian)'", available at: https://net.hr/danas/hrvatska/snimkakoja-dokazuje-da-nafta-jos-curi-policija-je-odmah-udaljila-novinare-ali-igradonacelnika-ae6da3d4-b lc2-1 1 eb-a981-0242ac13004d (December 12, 2020)

26. Perinić, J. (2007), "Crisis communication on the case of the tragedy of firefighters on the Kornati (in Croatian)", MediAnali, Vol. 1 No. 2, pp. 47-66.

27. Riffe, D., Lacy, S., Fico, F. (2014), Analyzing Media Messages Using Quantitative Content Analysis in Media Research, Routledge Taylor \& Francis Group, New York and London.

28. Romić, T. (2018), "Duspara: You can't attack us from the City and call us careless (in Croatian)", available at: https://www.vecernji.hr/vijesti/duspara-ne-mozete-nas-izgrada-napadati-i-prozivati-za-nebrigu-1238233 (December 12, 2020) 
29. The City of Slavonski Brod, Official Facebook page (2018a), "The City of Slavonski Brod hereby informs the citizens that the necessary water needed from the state stocks has been provided (in Croatian)", available at: https://web.facebook.com/gradslavonskibrod/posts/1684895641589510 (February 15, 2021)

30. The City of Slavonski Brod, Official Facebook page (2018b), "The City of Slavonski Brod hereby warns all citizens not to use drinking water in any way ... in Croatian)", available at: https://web.facebook.com/gradslavonskibrod/posts/1684537651625309 (February 15, 2021)

31. The City of Slavonski Brod, Official Facebook page (2018c), "The city has asked the County State's Attorney's Office to take all legally prescribed actions and initiate criminal proceedings... (in Croatian)", available at: https://web.facebook.com/gradslavonskibrod/posts/1685263571552717 (February 15, 2021)

32. The City of Slavonski Brod (2018a), "Drinking water is available in the area of all city local committees in Slavonski Brod (in Croatian)", available at: https://www.slavonskibrod.hr/vijesti/8328-pitka-voda-dostupna-je-na-podrucju-svih-gradskih-mjesnihodbora-u-slavonskom-brodu (February 15, 2021)

33. The City of Slavonski Brod (2018b), "We bring you a detailed list of locations and capacities of cisterns and drinking water tanks in the city area (in Croatian)", available at: https://www.slavonski-brod.hr/vijesti/8344-stozer-civilne-zastite-zatrazitce-od-nadleznog-ministarstva-dostavu-programa-sanacije-ekoloskog-akcidenta (February 15, 2021)

34. The City of Slavonski Brod (2018c), "Duty telephones of the City Administration for all inquiries of citizens about water supply and other important information (in Croatian)", available at: https://www.slavonski-brod.hr/vijesti/8326-dezurni-telefoni-gradskeuprave-za-sve-upite-gradana-oko-opskrbe-vodom-i-druge-vazne-informacije (February 15, 2021)

35. The City of Slavonski Brod (2018d), "Slavonski Brod and its surroundings will be connected to the water pumping station in Sikirevci, and until then the citizens will receive the necessary drinking water from the state commodity stocks (in Croatian)", available at: https://www.slavonski-brod.hr/vijesti/8323-slavonski-brod-i-okolica-bit-cespojeni-na-vodocrpiliste-u-sikirevcima-a-gradani-ce-do-tada-dobivati-potrebnu-pitkuvodu-iz-drzavnih-robnih-zaliha (February 15, 2021)

36. The City of Slavonski Brod (2018e), "The Civil Protection Headquarters will request the ministry in charge to submit a program for the remediation of the environmental accident (in Croatian)", available at: https://www.slavonski-brod.hr/vijesti/8344stozer-civilne-zastite-zatrazit-ce-od-nadleznog-ministarstva-dostavu-programasanacije-ekoloskog-akcidenta (February 15, 2021)

37. The City of Slavonski Brod (2018f), "Duspara orders; by blaming others and telling untruths, you will not return drinking water to the people of Brod! (in Croatian)", available at: https://www.slavonski-brod.hr/vijesti/8336-duspara-porucujesvaljivanjem-odgovornosti-na-druge-i-iznosenjem-neistina-necete-vratiti-pitku-vodubrodanima (February 15, 2021)

38. The City of Slavonski Brod (2021), "Public Relations - Press Releases (in Croatian)", available at: https://www.slavonski-brod.hr/gradska-uprava/odnosi-s-javnoscu/310objave-za-medije? start=50 (March 10, 2021).

39. Tkalac Verčič, A. (2105), Public Relations (in Croatian), Hrvatska udruga za odnose s javnošću, Zagreb.

40. Tomić, Z. (2016), Public Relations - Theory and Practice, Synopsis, Zagreb, Sarajevo.

41. Večernji list (2018a), "City officials claim: Gasoline has been leaking for six days, criminal charges have been filed (in Croatian)", available at: https://www.vecernji.hr/vijesti/gradske-vlasti-tvrde-benzin-curi-vec-sest-dana-1236829 (December 12 2020)

42. Večernji list (2018b), "More and more citizens are sick, complaining of diarrhea and vomiting (in Croatian)", available at: https://www.vecernji.hr/vijesti/u-sl-brodu-svevise-gra-ana-bolesno-zale-se-na-proljev-i-povracanje-1237146 (December 12 2020) 
43. Vecernji.hr, Hina (2021), "Petrol took over Crodux, the company of retired General Ivan Cermak (in Croatian)", available at: https://www.vecernji.hr/biznis/petrolpreuzeo-crodux-tvrtku-umirovljenog-generala-ivana-cermaka-1461284 (January 26 2021)

\section{About the authors}

Antonela Zora Rezo is an expert associate in the International Office of the Faculty of Forestry and Wood Technology in Zagreb. She is a public relations and scientific media research professional graduated from the Catholic University of Croatia (Zagreb). She got her master's degree on crisis communication: water pollution in Slavonski Brod - case study. The author can be contacted at: antonela_zora_rezo@hotmail.com.

Matilda Kolić Stanić, Ph.D., is a postdoctoral fellow at the Catholic University of Croatia (Zagreb). She graduated from the Pontifical University of the Holy Cross in Rome, where she got her Ph.D. with the topic "Fundamental criteria of public relations in codes of ethics. A comparison with the ethical criteria of journalism according to Luka Brajnovic". Her research interests include the ethics of public relations, media relations, theory, history of public relations, and crisis communication. The author can be contacted at: matilda.stanic@unicath.hr.

Marijana Togonal is an Assistant Professor at the Department of Communication Sciences at the Catholic University of Croatia, where she teaches classes in language and communication. She graduated from the Faculty of Humanities and Social Sciences and defended her Ph.D. at the Faculty in 2014. Her scientific interest is focused on language, public communication, and written tools for public communication. The author can be contacted at: marijana.togonal@unicath.hr. 